\title{
Creating Democratic Society: Howdo Malang's Instagram Influencers Use Their Freedom of Expression and Speech?
}

\author{
N Kholis ${ }^{1}$, N Husna ${ }^{2}$, G Asavitri ${ }^{3}$, Y Prisca ${ }^{4}$ \\ ${ }^{1,3}$ Communication Science Program, Institut Teknologi Bina Nusantara, Malang, Indonesia \\ ${ }^{2,4}$ Public Relations Program, Institut Teknologi Bina Nusantara, Malang, Indonesia
}

${ }^{1}$ nur.kholis001@binus.ac.id

\begin{abstract}
Creating democratic society is one of the main goals in democratic era. In the digital era, democratic society will be realized when the society member can freely use the freedom of expression and speech in social media. Social media is an independent media since it is not owned and controlled by political rulersunlike some of conventional media in Indonesia. As one of the most popular social media with 700 million of monthly active users in 2017, Instagram has a chance to be used as a media to controlthe democratization process in Indonesia. One of the basic principlesof democracy practice is freedom of expression and speech as provided for in article 28 of The 1945 Constitution of The Republic of Indonesia.It is the essential thing since every citizen is possible to deliver opinion about everything that matters.As part of Indonesian, Instagram influencers in Malang which are dominated by young generation play an important role in the democratization process itself. Toward their Instagram account, they can spread an influence to the society through their postby using their freedom of expression and speech. The research is done to discover how do Instagram influencers in Malang use their freedom of expression and speech as the representation of democracy in the democratic society. Based on the topics, qualitative research method was conducted, interview with informants that chosen purposively was gathered. Results showed that Instagram influencers in Malang use their freedom of expression and speech in two ways. First they use them to show their personal identity related to the job they have. Second, they use them to get a social utility in order to acquire information for conversation. Unfortunately,they did not use their freedom of expression and speech to criticize government policy since they do not interest in politics and afraid of being sued for it.
\end{abstract}

Keywords: Freedom, Democratic, Social Media

\section{INTRODUCTION}

Creating democratic society is one of the main goals in democratic era. In the democracy era, every citizen has an absolute right to be free in using expression and speech as provided for in article 28 of The 1945 Constitution of The Republic of Indonesia.Meanwhile, in the digital era, the practice of freedom of expression and speech can be delivered in a social media. Unlike some of conventional media in Indonesia, social media is an independent one since it is not owned and controlled by political rulers. The content that appears on a social media is 
personally comes fromthe user, not the ruler.As one of the most popular social media with 700 million of monthly active users in 2017 , Instagram can also be used as a media to deliver the freedom of expression and speech by its users.January Research by eMarketer in 2016 stated that the social media which provides photos journal and short videoswas the second popular social media in Indonesia [1].

Instagram influencers, those who are popular in social media Instagram has a big role to keep the democratization in its track by using their right in delivering freedom of expression and speech. As young and productive generation, they can deliver their opinion towards current issues by posting a related content so that their followers can be influenced and do the same good thing. The research is done to discover how do Instagram influencers in Malang use their freedom of expression and speech in their Instagram account since it becomes very important phenomenon nowadays for two reasons. Firstly, freedom of expression and speech is the representation of human rights and democracy practice. If Indonesian are not afraid of using them in public, it may be concluded that the democratization process itself is well applied in the country. Secondly, the future of democracy in Indonesia is determined by the young generation. It refers to the critical thinking about current issues such as government policies that is delivered in a public sphere.

As one of developed cities with many educational institutions and millennial generation in Indonesia, Malang has a big role to oversee democratization process in this country.As many of young generation are active in using social media, therefore the research will discover how do Instagram influencers use their freedom of expression and speech. Instagram influencers in Malang are the representative of how young generation in Malanguse social media. The objective of the research is aimed to describe how far freedom of expression and speech is used in a social media sphere. The result of the study itself is expected to be a basis ofevaluation for the democratization process in Indonesia in the effort of creating democratic society.

Motive is the most essential thing that motivates people to do or not to do something.Motivation in using social media will be the main subject to get to know how doInstagram influencers in Malang City use their freedom of expression and speech.The study appliesuses and gratifications theory to get more comprehensive understanding about motives themselves.

\subsection{Motivation in Using Social Media}

Motives described as general tendencies that affect people's behaviors taken to satisfy need or desire [2]. According to Lai [3], motivation is classified into two types, they are intrinsic and extrinsic. Intrinsic motivation refers to personal enjoyment, interest or pleasure, meanwhile extrinsic motivation refers to chance reinforcement's influence. Meanwhile, Morris and Ogan [4] explained that online communications are mass media with the ability to satisfy interpersonal and mediated needs. Specifically, social media enable individuals to have real time and interpersonal communication in mediated forms [5], [6]. The other study[7] found that there are some motivations people use an online media through computer and social media. They are to satisfy: (a) interpersonal needs (inclusion, affection, control, relaxation, escape and enjoyment); (b) mediated needs (social interaction, passing time, habit, knowledge and leisure); and (c) other needs (time shifting and making new friends). 


\subsection{User and Gratification}

According to Rubin, the essential part of uses and gratifications is audience activity[8], meanwhile the main element of it is communication motivations.Moreover, uses and gratifications also describes about motivations in using a media. For instance, it functions as diversion (as an escape from routines or for emotional release), social utility (to acquire information for conversations), personal identity (to reinforce attitudes, beliefs and values), surveillance (to learn about one's community, events and political affairs) [9].

Another statementmentioned by Effendy[10]that uses and gratifications starts in the social environment refers to the needs of audiences. There are some reasons why Instagram users post pictures, they are:

- Cognitive needs (knowledge)

It refers to the requirement of information confirmation and knowledge as well as understanding environment. These requirements are based on a desire to understand and master the environment as well as to satisfy curiosity and the urge for investigation.

- Affective needs (experiences)

It refers to an individual needs of reassurance over aesthetic, fun and emotional experiences.

- Personal integrative needs (personal identity)

It refers to confirmation needs which are related to credibility, trust, stability, and individual status, which derived from desire forself-esteem.

- Social needs (social identity)

It refers to the needs of confirmation to maintain relationship with family, friends and the world which are based on a desire to affiliate.

- The escapist needs (need to release tension).

It refers to the desire to escape from reality, release emotions, tension and entertainment needs.

Nowadays, social media can be used to interact each other through the shared information and experiences [10]. The interaction through social media enablesits users to get to know each other and become a source of trust [11].This condition allows people to be inspired by someone's content. In the case of Malang's Instagram Influencers, they actually can be someone who can influence their followers to do or not to do something. Meanwhile, the practice of freedom of expression and speech can be delivered through their posts on Instagram. In conclusion, social media like Instagram can be a representative of a democracy practice, especially by the young generation who use it. The subject that really matters is about how do the users deliver the freedom of expression and speech through every contents they post and share to their followers.

\subsection{Freedom of Expression and Speech}

Freedom of expression and speech in Indonesia is provided for in article 28 F 1945 Constitution [12]. It is stated thatIndonesian citizen are freely to deliver opinion and get information: Everyone shall have the right to communicate and obtain information to develop his or her personal and social environment, and shall have the right to seek, obtain, possess, store, process and convey information using all available channels. Moreover, article 5, Number 9 of Constitution 1998 states that Indonesian citizen has a right and legal protection to use theirfreedom of expression of public opinion. 


\subsection{Instagram and Its Influencers}

Today, Instagram is the second popular social media in Indonesia after Facebook.There are several factors that contribute to it, as it is stated by Bolt [13] as follows:

- Quality

Instagram has a sameness in quality and visual appeal as phone apps completed with simple and well designed interface to let users use photo filters before posting pictures.

- Audience

It enables the user (follower) to give feedback by giving a like, comment or favorite.

- Constraint

Instagram enables its users to be creative in producing their contents through instant online photo and video editor.

Based on its popularity, Instagram has successfully created its own community that is involved the account owner and followers. Influencer Marketing Hub.com [14] states that someone who can give a value through his own expertise with good internet personality is categorized as an influencer. Instagram influencer is not always related to the number of followers but also the engagement between the account owner and followers.

\section{METHOD}

This study is a qualitative descriptive research that aims to discover how do Instagram Influencers in Malang City use their freedom of expression and speech. Meanwhile, uses and gratifications theory is appliedto analyzeit. Qualitative research aims to understand the phenomenon that is experienced by the subjects holistically and it is described in the form of words and language. Moreover, Ruggiero [9] suggests the researchers to conduct qualitative methodologieswhich is in line with the application of uses and gratifications theory.

Data is compiled by using deep interview with informants that are chosen purposively. The informants are Instagram Influencers in Malang whose have at least 5.000 followers with hundreds or thousands of likes, views and comments. They are also 20 up to 34 years old whose categorized as millennia generation. The informants are also active to post a content through photos, videos in timeline or Instagram story at least once a day.Based on the researcher's observation, there are approximately 20 to 30 Instagram influencers in Malang, meanwhile this study selected 4 of them. They are:@onengsugiarta whose has 14.2k followers, @ denyeka_ whose has 7.657 followers, @justine_viddy with her 8.377 followers and @ reerinatawith her 7.726 followers.

\section{RESULT AND DISCUSSION}

Interview with informants results some findings related to how do Instagram Influencers in Malang use their freedom of expression and speech, as follows:

- They use freedom of expression and speech in order to show their personal identity. It refers to the job they have. Instagram influencers in Malang whose most of them areshowbiz performer tend to share their activity while working. Based on the theoretical framework, this activity refers tointrinsic motivationand relates to personal enjoyment, interest or pleasure. Interview with MC OnengSugiarta and MC Deny Eka proves that theytend to express their freedom of expression and speech through their personal identity's post. As professional Master of Ceremony, they need to show their followers the job they have. They do believe that by showing their job activity, their personal 
identity as a professional showbiz performer will be stronger and result another new opportunity for their career. They share it to strengthen their identity as a performer as it is shown to these pictures:

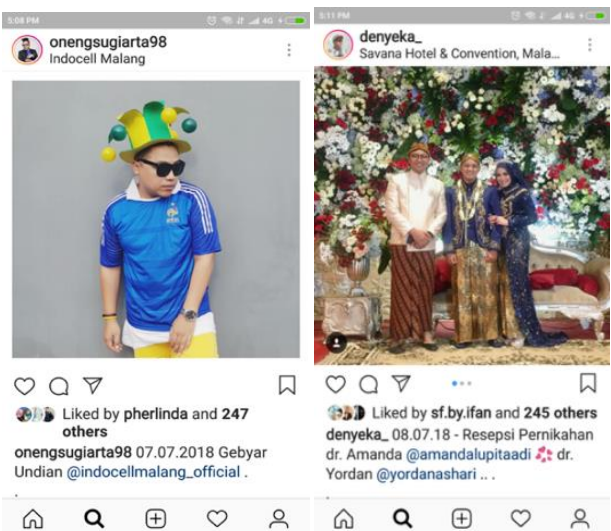

Figure 1. Malang;Instagram Influencer Expresses Their Personal Identity.

- They use freedom of expression and speech in order to get a social utility to acquire information for conversation. It is in line with a theory that people tend to use computer through social media to get an interaction with other users as it is shown through these pictures:

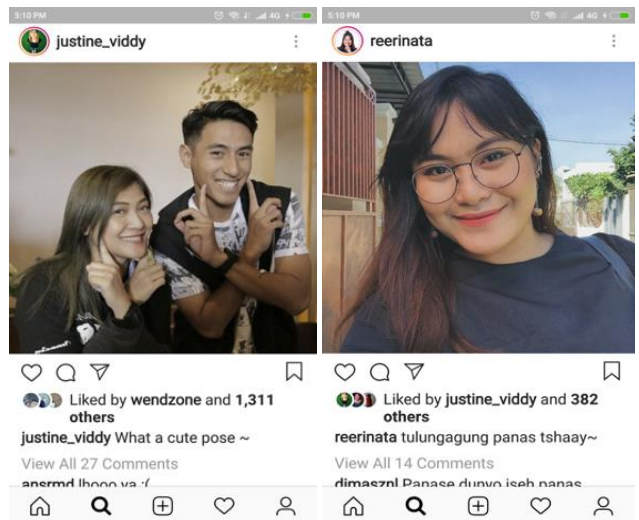

Figure 2. Malang;Instagram Influencer Expresses Their Social Utility.

Justine Viddyand Renata Angel are two of famous Instagram influencer in Malang City. They are professional radio announcer, Master of Ceremony and also actress for Darah Biru Arema, a local movie that portrays the story of supporter of Malang's Football Team, Arema. Both of them use their freedom of speech and expression through the post that is intended to get a social utility to acquire information for conversation. The inserted caption in the picture they post is very attractive that enables their followers to give likes and comments. These activities bring up the influencers and followers to interact and be informedto each other. This activity is in line with mediated needs theory that is involved: social interaction, passing time, habit, knowledge and leisure.

Instagram influencers in Malang use their freedom of expression and speech in two ways, they are: to show their followers their personal identity and to get a social utility to acquire 
information for conversation.Based on the study literature above, these two findings are closely related to the intrinsic motive rather than extrinsic one since it refers to personal enjoyment, interest or pleasure. Meanwhile the findings is also refers to other motive, it is about satisfyinginterpersonal needs (inclusion, affection, control, relaxation, escape and enjoyment) and for mediated needs (social interaction, passing time, habit, knowledge and leisure). In conclusion the motive of the Instagram influencer is about to interact to each other.

In the case of MC OnengSugiarta and MC Deny Eka, freedom of expression and speech are used through the style they perform in the picture and caption they write. They focus on expressing their personal identity by showing their followers their activity while working as a Master of Ceremony. They do really hope that their personal identity will be stronger so that their professional career will be improved significantly. Meanwhile, in the case of Justine Viddy and Renata Angel, the freedom of expression and speech refers to the effort to get a social utility and acquiring information for conversation. They are freely to post a caption that represents what they think at the moment. Surprisingly, they got a lot of comments that is possibly improve their engagement with followers. The researchers may conclude that Instagram influencers in Malang city have actually delivered their freedom of expression and speech properly in a personal sphere. The researchers define personal sphere as a professional and personal identity which is related to the job they have.

Unfortunately, Instagram influencers in Malang did not interest to use their freedom of expression and speech to criticize government policy. They admit that they are not interested in politics. They are also afraid of being sued for it. Due to the finding, government of Indonesia should provide and declare the regulation of using social media clearly, especially to the millennialgeneration. It is important since they do need to know better about the regulationwhen expressing the freedom of expression and speech through social media. It is also very essential for the future of democratization process in Indonesia.

\section{CONCLUSION}

The study is limited only in finding how Malang's Instagram Influencer use their freedom of speech and expression. Meanwhile the finding shows that still there is an obstacle for the user of Instagram to show their opinion about government policy or any topics related to politic. Due to the finding, the researchers suggest other researchers to investigate why do young generation are not interested in politics and afraid of being sued for criticizing government policies. Meanwhile, the researchers also suggest to do a quantitative research due to the same topic in order to get more comprehensive understanding about it.

\section{ACKNOWLEDGEMENTS}

The authors gratefully acknowledge that the present research is supported by Malang Kipa, a community of social media influencer and administrator in Malang City for the development of the digital strategic communication practices nowadays.

\section{REFERENCES}

[1] S. Loras, "Social Media in Indonesia: big numbers with plenty of room to grow," Click Z, 2016. [Online]. Available: https://www.clickz.com/social-media-in-indonesiabig-numbers-with-plenty-of-room-to-grow/94062/.

[2] J. J. Al-Menayes, "Motivations for Using Social Media: An Exploratory Factor 
Analysis," Int. J. Psychol. Stud., vol. 7, no. 1, Feb. 2015.

[3] E. R. Lai, "Motivation: A literature review," United States, 2011.

[4] M. Morris and C. Ogan, "The Internet as Mass Medium," J. Commun., vol. 46, no. 1, pp. 39-50, Mar. 1996.

[5] K. Baek, A. Holton, D. Harp, and C. Yaschur, "The links that bind: Uncovering novel motivations for linking on Facebook," Comput. Human Behav., vol. 27, no. 6, pp. 2243-2248, 2011.

[6] J. Lee, M. Lee, and I. H. Choi, "Social Network Games Uncovered: Motivations and Their Attitudinal and Behavioral Outcomes," Cyberpsychology, Behav. Soc. Netw., vol. 15, no. 12, pp. 643-648, 2012.

[7] L. M. Flaherty, K. J. Pearce, and R. B. Rubin, "Internet and face-to-face communication: Not functional alternatives," Commun. Q., vol. 46, no. 3, pp. 250-268, Jun. 1998.

[8] A. M. Rubin, "The Uses-and-Gratifications Perspective of Media Effects," in Media Uses and Effects, J. Bryant, D. Zillmann, J. Bryant, and M. B. Oliver, Eds. NJ: Erlbaum: Hillsdale, 1994, pp. 417-436.

[9] T. E. Ruggiero, "Uses and Gratifications Theory in the 21st Century," Mass Commun. Soc., vol. 3, no. 1, pp. 3-37, Feb. 2000.

[10] S. Senecal and J. Nantel, "The influence of online product recommendations on consumers' online choices," J. Retail., vol. 80, no. 2, pp. 159-169, Jan. 2004.

[11] Y. Lu, L. Zhao, and B. Wang, "From virtual community members to C2C e-commerce buyers: Trust in virtual communities and its effect on consumers' purchase intention," Electron. Commer. Res. Appl., vol. 9, no. 4, pp. 346-360, Jul. 2010.

[12] A. Adzkia, "Indonesia Darurat Kebebasan Berekspresi," CNN Indonesia, 2016. [Online]. Available: https://www.cnnindonesia.com/nasional/20160510104959-21129644/indonesia-darurat-kebebasan-berekspresi.

[13] N. Bolt, "Why Instagram Is So Popular: Quality, Audience, \& Constraints," Techcrunch, 2011. [Online]. Available: https://techcrunch.com/2011/11/27/whyinstagram-is-so-popular/.

[14] W. Geyser, "Meet The Top 25 Influencers Crushing It On Instagram," Influencer Marketing Hub, 2018. [Online]. Available: https://influencermarketinghub.com/top25-instagram-influencers/. 